\title{
プレストレストコンクリート骨組構造の耐震特性についての一考察 \\ STUDY ON EARTHQUAKE RESISTANCE CHARACTERISTICS OF PRESTRESSED CONCRETE FRAME STRUCTURES
}

\author{
岸本一蔵, 吉田哲也**, 池宮 学***, 梁野 慶**** \\ 中塚 佶*****, 大野義照****** \\ Ichizou KISHIMOTO, Tetsuya YOSHIDA, Manabu IKEMIYA, \\ Kei FUKANO, Tadashi NAKATSUKA and Yoshiteru OHNO
}

\begin{abstract}
In order to improve the understanding of earthquake resistance characteristics of prestressed concrete (PC) structures designed by the current design method (route-3a), the following researches had been performed : (1)Determination of earthquake load, dead or live loads and indeterminate force in design. (2) Comparison between ultimate strength of PC beam, strength developed by PC bars in the PC beam section and required strength of beam in design. (3) Comparison between ultimate strength of columns and required strength of column in design. (4) Static elasto-plastic analyses of designed frame. The main result of this study is that equipment of PC bars in beam section is not a factor in over-strength against required strength in design and PC frame structure has the story whose shear strength is lowest of all stories in the structure essentially and this feature is caused by the large dead or live load of the structure.
\end{abstract}

Keywords: Prestressed concrete frame structure, earthquake resistance characteristics, design bending moment, ultimate strength, analytical investigation PC フレーム構造、耐震性能、設計用応力、終局曲げ耐力、解析的検討

\section{1. はじめに}

現行のプレストレストコンクリート（以下 PC と略記）構造の耐震 設計は、保有耐力に基づく設計に代わるものとして終局強度型の設計 法が採用される場合が多い。しかしながら、その基本となる而震特性 については解明すべき点が少なくなく、未だ確立された設計法とは言 い難い。

一方、現在の建築基淮法の改正以後約 16 年が経過し、耐震設計に 関する研究む進み、さらに 1995 年の兵庫県南部地震を受けて建築基 淮法の改訂作業が行われている。その内容は、想定する変形（設計限 界等）において所定の耐力を確保することを基本とした性能規定型の 設計法へ移行が予見される。これに忘じて、日本建築学会では日本建 築学会:鉄筋コンクリート造建物の勒性保証型耐震設計指針（案）・同 解説 1)を公表している。同案の提案は、変形レベルに応じて建物の保 有する耐力および各構造部材の状態が規定されるものであり、設計者 の工学的判断が従来以上に要求されるより自由度の高い設計法であ る。この様な設計法への移行を考える場合、様々な点において現行設 計法の考え方がその拠り所となることは十分に考えられ、現行設計法 により設計された建物の構造的特性を検討しておくことは非常に重 要となる。

PC 構造では、大スパン架構、PC 鋼材の配置という2つの特徵が、
建物の特性に大きく影響すると考えられ、耐震性能から見た場合次の 点が重要となる。（1)鉄筋コンクリート（以下 RC と略記）構造に比 ベ大きい鉛直荷重時応力、プレストレスト導入に伴い発生する不静定 応力。これらが設計をどの様に支配しているのか。(2) PC 鋼材配置に 起因する部材曲げ耐力の上昇が、梁のヒンジ形成を前提とした設計を 困難にするとされているが、どの様な条件において困難となるのか。 (3) (1)での問題との関連で、柱の部材曲げ耐力の分布がどの様な特徵 をもつのか。またその特徵が建物終局時におけるヒンジ発生ヶ所、お よび崩壊型とどのような関連をもつのか。(4) PC 部材の高復元力特性、 即ちエネルギー吸収能が小さいという特性は、地震時の建物応答にど のような影響をおよぼすのか。これらの問題のうち(4)については、層、 或いは部材の履歴特性を考慮した地震応答解析を行い、PC 建物の応 答性状を RC 建物のそれと比較検討した研究がいくつか発表されてい る 2、3)。これに対し、(1)〜(3)の問題に関して検討された研究は皆無で あり、またその検討方法についても明確な手法も確立されていない。

本論文は、 PC 骨組建物の而震特性に対する基礎資料を得ることを 目的に、現行設計法（建設省告示 1320 号 設計ルート 3-a 型）に準拠 して試設計した骨組モデルに対し、設計用忘力に関する検討、設計用 応力と部材の曲け耐力の比較による検討、静的弾塑性解析結果等から、 上記(1)〜(3)の問題について考察を試みたものである。

\footnotetext{
* 大阪大学工学部建築工学科 助手 . 工修

**大林組東京本店 工修

***大阪大学工学部建築工学科 大学院生

**** 大林組本店建築設計第 6 部設計課 諜長・博士 (工学)

***** 大阪大学工学部建築工学科 助教授・工博

****** 大阪大学工学部建築工学科 教授・工博

Research Assoc. Dept. of Architectural Eng. Fac. of Eng., Univ. of Osaka, M. Eng. Obayashi Corp., M. Eng.

Graduate Student, Dept of Architectural Eng. Fac. of Eng., Univ. of Osaka

Manager of Design Section, Design Dept. Obayashi Corp., Dr. Eng.

Assoc. Prof., Dept. of Architectural Eng. Fac. of Eng., Univ. of Osaka, Dr. Eng.

Prof., Dept. of Architectural Eng. Fac. of Eng., Univ. of Osaka, Dr. Eng.
} 


\section{2. 試設計モデル}

\section{1 設計条件}

試設計建物は、 5 層（高さ約 $20 \mathrm{~m}$ ）、8 層（約 $30 \mathrm{~m}$ ）および 12 層（約 $45 \mathrm{~m}^{* 1}$ ) で、柱を RC 構造、梁を PC 構造としだ純フレーム架構の一般 事務所ビルとした (図 1 参照)。スパン長 (L) は、15、20、25m の3 種類とした。表 1 に設定したモデル一覧を示す。ここで単えパンモデ ルを採用した理由は、単スパン構造が PC 構造では特殊なものではな く、各層が 2 本の柱と 1 本の梁から構成される最も単純な構造形式で あるため、モデルの柱・梁断面性能の決定及ひ架構の基本特性の把握 が比較的明解であり、一般的な PC 構造の基本データを示すものと判 断したためである。

モデルを構成する柱・梁の断面寸法は各モデル毎に以下の方針で設 定した。P C構造の梁のせいは、スパン長さの 1/15 から 1/20 が一般 的とされているが、本研究では筆者らの既往の研究成果 ${ }^{4,5)}$ に基づい て、スパン長さの約 1/17〜1/19 である 900(L=15m モデル)〜 $1300 \mathrm{~mm}(\mathrm{~L}=25 \mathrm{~m}$ モデル)を全層について共通とした。梁幅はもデル高さ による応力の大小を考虑して 550 から $700 \mathrm{~mm}$ の間の值とした。柱に ついては、一般的に柱軸力比及びせん断耐力が骨組構造の耐力を直接 支配する要因とされているので、設計用ベースシアー係数(以下 CB と 略記)を 0.40 、せん断力分布形を $\mathrm{Ai}$ 分布形として求めた設計用せん断 力による柱応力に対して、次の 2 条件を満足するように断面寸法（正 方形断面)を設定した。(1)柱軸力については、軸方向応力度が $0.35 \mathrm{Fc}$ (昭 56 住指発第 96 号による部材ランク FA に対応)以下とする。(2)せん断 力については、応力割増等を考慮せずに同指針のせん断耐力式にて算 定されたせん断耐力を下回る。ここで特に CB を 0.40 に設定した理由 は、CB を 0.20 とした通常の一次設計用せん断力に対して骨組がその

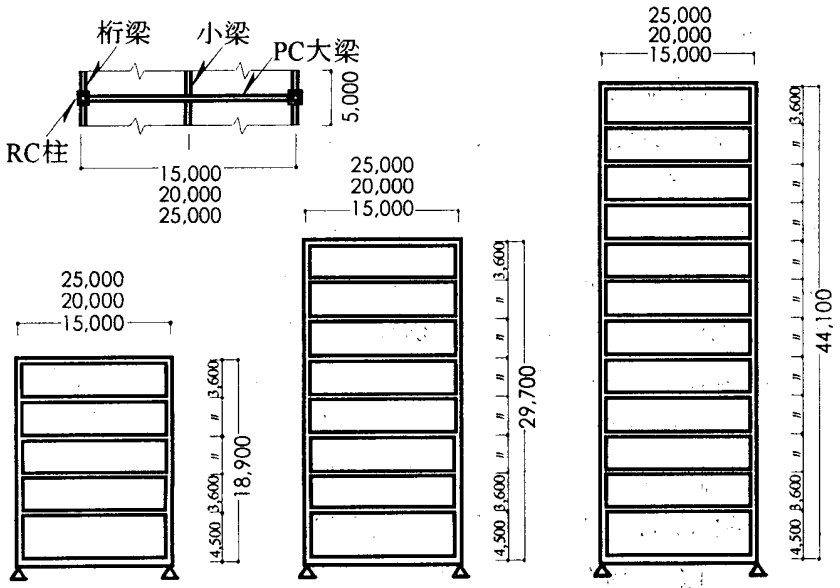

図-1＼cjkstart試設計モデル

表-1＼cjkstart試設計モデル一筧

\begin{tabular}{|c|c|c|c|}
\hline 階数 $(n)$ スパン長 $(L)$ & $15 m$ & $20 m$ & $25 m$ \\
\hline 5 階建て & 5 層L $=15 \mathrm{~m}$ & 5 層 $L=20 \mathrm{~m}$ & 5 層L $=25 \mathrm{~m}$ \\
\hline 8 階建て & 8 層 $L=15 \mathrm{~m}$ & 8 層 $L=20 \mathrm{~m}$ & 8 層 $\mathrm{L}=25 \mathrm{~m}$ \\
\hline 12 階建て & 12 層 $L=15 \mathrm{~m}$ & 12 層 $\mathrm{L}=20 \mathrm{~m}$ & 12層 $\mathrm{L}=25 \mathrm{~m}$ \\
\hline 備考 & \multicolumn{3}{|c|}{ 全モデル共 $\mathrm{CB}=0.30 、 \mathrm{Ai}$ 分布型にて設計 } \\
\hline
\end{tabular}

*1 $^{1}$ 本来 $31 \mathrm{~m}$ を超える建物は設計ルート $3 \mathrm{a}$ の対象外
2.0 倍程度の水平耐力を保有することは充分一般的であると考えた為 である（一例として 8 層 L=15m モデルの断面寸法を表 2 に示す）。

主筋および PC 鋼材量を決定するための設計用応力は、建設省告示 に従い地震時応力、鉛直荷重 (自重十積載荷重)、時応力および不静定 応力を考慮した。地震時応力は、建築基淮法施行令で規定する地震荷 重 $(\mathrm{CB}=0.2$ ど $\mathrm{Ai}$ 分布形) による弾性応力を 1.5 倍（即ち $\mathrm{CB}=0.3 ）$ と したものとし、固定、積載荷重は一般事務所ビルの建物諸元及び建築 基準法施工令に準拠した。不静定応力は、梁の PC 鋼材をプレストレ ストコンクリート設計施工規淮・同解説 ${ }^{6}{ }^{6}$ の付録 7 : case2 のように配 置し、梁部材中央位置において断面の最下端の応力が零になる条件よ り PC 鋼材量を求め、その量を基に文献 6 の算定規定に従い計算した。 施工順序については、各層打ち込み後、所要強度に達した後にプレス トレスを導入するものとした。以上、各応力の算定にあたっては、架 構の初期剛性に基づいた弾性解析を行った。

使用材料については、コンクリート圧縮強度について柱は FC270、 梁は FC360 とした。柱の主筋量は、鉄筋コンクリート構造計算規 準・同解説》の柱の曲げ終局強度の略算式を、また梁の主筋量は、プ レストレストコンクリート設計施工規準・同解説の曲げ破壊耐力の計 算の条項をそれぞれ用いて求めた。なお、本研究は柱・梁の終局曲げ 耐力（以下 曲げ耐力と略記）に関する検討を目的としていることか ら、設計でのせん断力に対する評価等は行っていない。

\section{2 設計用応力の検討}

PC 建物では、大スパン構造であることに起因して鉛直荷重時応力 が大きく、またプレストレス遒入に伴う不静定応力が存在することが 大きな特徵である。これらの応力は、設計用応力算定に考慮され、断 面配笳を決定している。即ちこれらの応力は断面の曲げ而力、ひいて は架構全体の耐震性を間接的に決定している。

本項では、設計用応力算定に考慮されている地震時応力、鉛直荷重 時応力、不静定応力の大きさの比較、および設計用応力そのものの大 きさを検討することにより、設計に対しこれらの応力がどの程度影響 しているのかを考察し、後で述べる部材の曲け耐力余裕度（部材の曲 げ耐力の設計用応力に対する比率) 分布の検討を行う上での資料とす

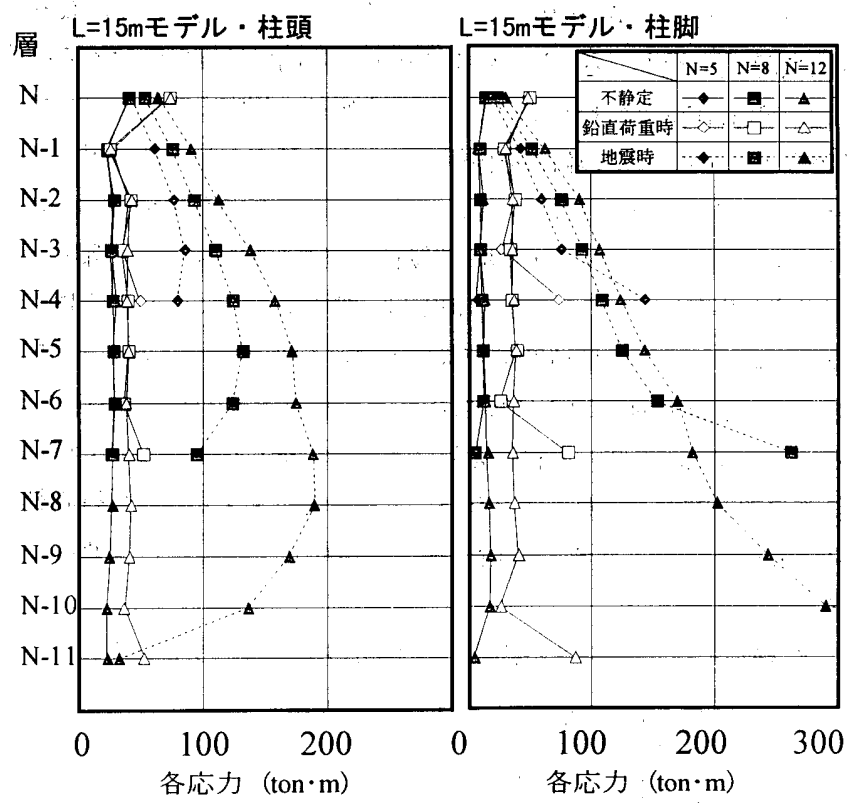

図-3 地震時、鉛直荷重時、不静定の各応力の層方向の分布 
る。

検討を行う上で、モデルの最上層および最下層の節点では、柱と梁 が 1 対 1 で接続しており、柱と梁が 2 対 1 で接続する一般首とは応力 分布が著しく異なるため、本節では文中に特に記述が無い場合は検討 の対象とせず、今後の課題としている。

図 3 は、層数が 5、8、12 層で $\mathrm{L}=15 \mathrm{~m}$ であるモデルの柱について、 地震時応力、鉛直荷重時応力、不静定応力の層方向の分布状態を、最 上層（ $\mathrm{N}$ 層）を起点として柱頭、柱脚別に示したものである。同図に よれば、地震時応力は当然のことながら基本的に下層に向かう程増加 する。また、不静定応力は柱頭では下層程やや小さくなる傾向を、柱 脚ではやや大きくなる傾向を示している。これに対し、鉛直荷重時応 力は建物の層数によらず、全ての層でほぼ一定の值を示し、特に柱頭、 柱脚でその大きさに殆ど差がないことがわかる。この傾向は他の全て のモデルについて同様であった。それ故、鉛直荷重時応力を基準値 (100\%) として、各応力の大きさの比較を、比率により検討すること とし結果を図 4 に示す。

図 4 (a)は、 L=15m のモデルを用いて建物層数の影響をみたもので ある。地震時応力の鉛直荷重時応力に対する比（以下 地震時応力比 と呼ぶ) は柱頭、柱脚共に、下層ほど、また層数が多いモデルほど大
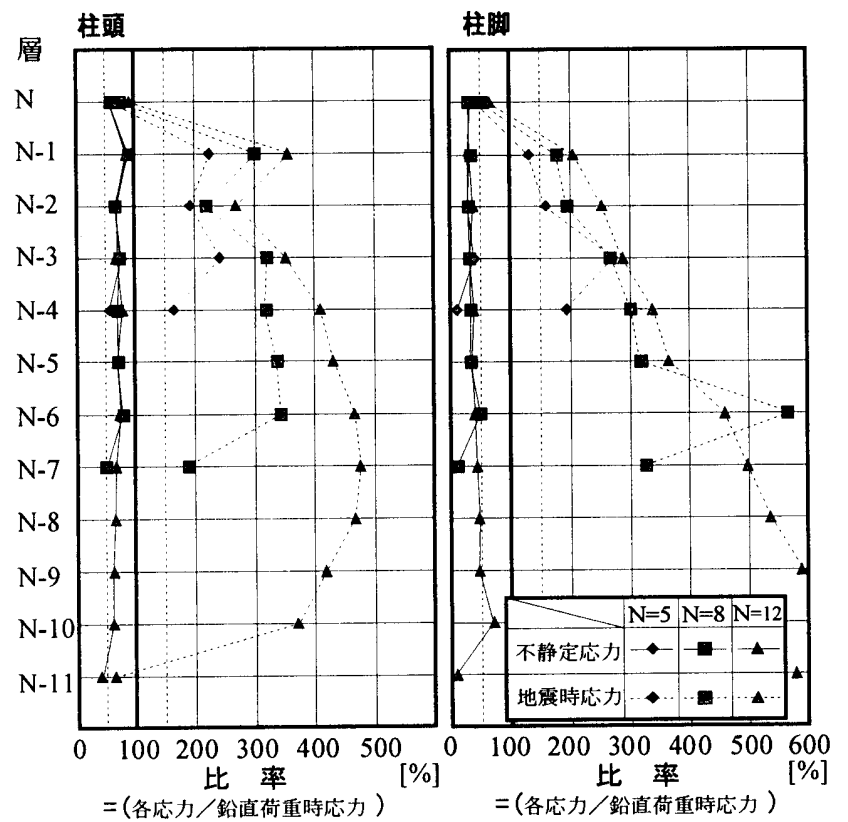

(a) L=15mモデル(建物層数の影部)

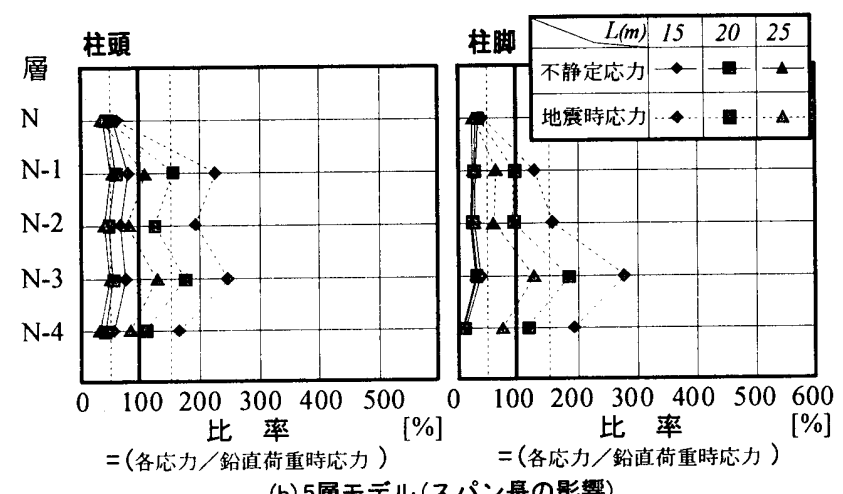

(b) 5 層モデル(スパン長の影帮)

図-4 地震時応力、不静定応力の鉛直荷重時応力に対する比率
きい值を示している。同応力比が最も小さくなる 5 層モデルく印)で も、最上層(N 層)を除いた全ての層で $100 \%$ 超えており、地震時応力 は鉛直荷重時応力に比べ大きいことが分かる。不静定応力の比は、前 述の通り柱頭では下層ほど、柱脚では上層ほど小さく、前者で約 $80 \%$ (N-1 層) 60\%(N-10 層)、後者で約 65\%( N-9 層) 約 35\% (N-1 層) である。

図 4(b)は、5 層の $\mathrm{L}=15 、 20 、 25 \mathrm{~m}$ のモデルを用いて、応力比に及ぼ すスパン長の影響をみたものである。スパン長が大きくなると各応力 の絶対量は増加するが、同図に示すように、スパン長の大きいモデル 程、各応力比は小さくなり、相対的に鉛直荷重時応力が他の応力に対 して大きくなることがわかる。例えば、 $\mathrm{L}=15 \mathrm{~m}$ のモデルでは、最上層 を除く全ての層で地震時応力が最も大きい荷重であったのに対し、

$\mathrm{L}=25 \mathrm{~m}$ のモデルでは、 $\mathrm{N}-1$ 層の柱頭と $\mathrm{N}-3$ 層の柱頭、柱脚を除いて全 ての層で鉛直荷重時応力が最も大きい荷重となっている。また不静定 応力比は、全ての層で、 $\mathrm{L}=25 \mathrm{~m}$ モデルでは $\mathrm{L}=15 \mathrm{~m}$ モデルの值に対し およそ半減した值となっている。

以上の各応力を用いて計算した設計用応力（地震時応力十鉛直荷重 時応力十不静定応力）、および各モデルにおける設計用軸力（地震時 変動柱軸力十鉛直荷重時柱軸力）を図 5 に示す。同図は、層数が 5、8、 12 層で $\mathrm{L}=15 \mathrm{~m}$ であるモデルの柱頭の例であり、図中の引張側（圧縮 側）とは、地震時の水平力に対し柱が引張（圧縮）を受ける側を指す。

図 5 より、引張側の設計用応力の值は、圧縮側の值に比べて全ての 層で小さく、両者の差の絶対值は層によらずほぼ一定（検討モデルの 場合約 50ton $\mathrm{m}$ ）であるから、両者の比率 (圧縮側の值/引張側の值) は上層部程大きく、逆に低層では小さいことが分かる。設計用軸力は、 上層では引張側と圧縮側の差は小さく、これに対し下層では両者の差 は大きくなっている。これらの傾向は、柱脚においても、またスパン 長が変化する場合でも同様であった。

設計用応力および設計用軸力に関する以上の傾向から、柱部材の曲 げ而对には次のような特徽があると推察される。建物上層部では、圧 縮側の設計用応力が大きく、引張・圧縮側の設計用軸力の差が小さい

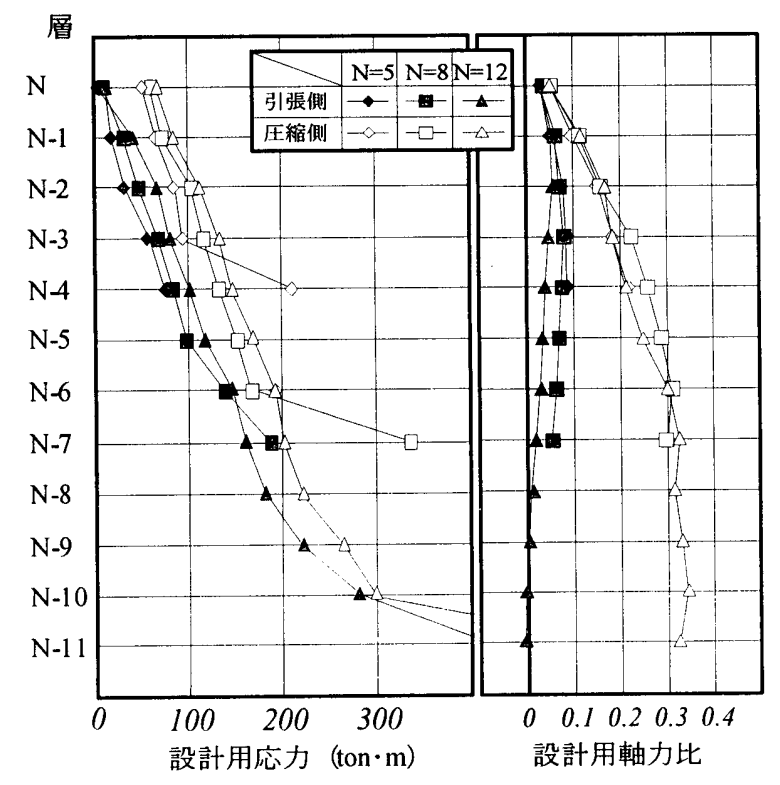

图-5 柱頭の設計用応カと設計用軸力（L=15mモデル） 
ことから、柱の主筋量は圧縮側の条件（設計用応力に対し要求される 鉄筋量) で決定され、従って引張側の柱の耐力は設計用応力に対して 余裕を生じる。建物下層部では、圧縮側の設計用応力は引張側に比べ て大きいものの、両者の差は上層部に比べ相対的に小さく、また圧縮 側の設計用軸力が引張側に対し大きな值となる。従って、柱の主筋量 は引張側の条件で決定され、圧縮側の柱の耐力は設計用応力に対して 余裕を生じる。更に、上層では引張側、下層では圧縮側に、設計用応 力に対する余裕があることから、両者の中間に位置するいずれかの層 では、引張、圧縮両側共に余裕が小さく、設計用応力（即ち地震時層 せん断力）に対し、相対的に弱い層が存在する。

以上に述べた柱耐力に関する傾向は、 RC 構造にもあてはまる傾向 であるが、鉛直荷重時応力が大きい PC 構造では、これらの傾向がよ り顕著に現れる事が予想される。後述する 3.3 では、各試設計モデル について具体的な検討を行う。

\section{3. 部材曲け耐力の検討}

地震時における建物のヒンジ発生籄所や崩壊型は、建物の持つ諸特 性だけでなく、地盤条件や地震波特性等様々な条件の影響を受けるこ とは自明である。しかし、基本的かつ最も直接的には、各部材の曲げ 耐力が建物内でどの様に分布しているかに関わる。

本節では、 3.2 項で梁部材について、3.3 項で柱部材について、部材 の曲げ耐力を設計用応力と比較することにより、建物のヒンジ発生箇 所と崩壊型について検討する。

\section{1 試設計モデルの断面と配筋量}

2 節で求めた設計用応力を用いて梁・柱の主筋量を決定した。具体 的には、設計用応力に対し部材の曲げ耐力がそれを超える最小限の量 を主筋量とした。表 2 に 8 層 $\mathrm{L}=15 \mathrm{~m}$ モデルについて断面及ひ配筋一 覧を例として示す（鉄筋本数は上述の理由により小数値となってい る）。なお、表 2 に示すように、最上層およびその下層における梁主 筋については、計算および解析の都合上 RC 梁で採用される最小鉄筋 量 $(\mathrm{pt}=0.4 \%)$ により決定された場合が存在するが、これは以後の検討

表-2 断面及び配筋一覧例 （8層 L=15mモデル）

\begin{tabular}{|c|c|c|c|c|c|}
\hline \multirow[b]{2}{*}{ 階 } & \multicolumn{2}{|c|}{ 柱断面 (上:柱頭 -下:柱脚) } & \multicolumn{3}{|c|}{ 梁断面 } \\
\hline & $\begin{array}{r}\text { 断面形状 } \\
\mathrm{BxD}(\mathrm{cm})\end{array}$ & 配箭 & $\begin{array}{r}\text { 断面形状 } \\
\mathrm{BxD}(\mathrm{cm})\end{array}$ & $\begin{array}{l}\text { 緊張材 }{ }^{*} \\
\text { (本数) }\end{array}$ & $\begin{array}{c}\text { 配筋 } \\
(y=1.0)\end{array}$ \\
\hline 8 & $70 \times 70$ & $\begin{array}{l}4.8-\mathrm{D} 29 \\
3.0-\mathrm{D} 29\end{array}$ & $55 \times 90$ & 6 & $3.9-\mathrm{D} 25^{* *}$ \\
\hline 7 & $70 \times 70$ & $\begin{array}{l}3.7-\mathrm{D} 29 \\
2.5-\mathrm{D} 29\end{array}$ & $55 \times 90$ & 5 & 3.9-D25 ** \\
\hline 6 & $75 \times 75$ & $\begin{array}{l}3.3-\mathrm{D} 29 \\
2.8-\mathrm{D} 29\end{array}$ & $55 \times 90$ & 5 & $5.6-\mathrm{D} 25$ \\
\hline 5 & $75 \times 75$ & $\begin{array}{l}4.5-\mathrm{D} 29 \\
2.4-\mathrm{D} 29\end{array}$ & $60 \times 90$ & 5 & 8.6-D25 \\
\hline 4 & $80 \times 80$ & $\begin{array}{l}4.7-\mathrm{D} 29 \\
2.9-\mathrm{D} 29\end{array}$ & $60 \times 90$ & 5 & $11.1-\mathrm{D} 25$ \\
\hline 3 & $85 \times 85$ & $\begin{array}{l}\text { 4.7-D29 } \\
\text { 3.3-D29 }\end{array}$ & $60 \times 90$ & 5 & $13.1-\mathrm{D} 25$ \\
\hline 2 & $90 \times 90$ & $\begin{array}{l}4.0-\mathrm{D} 29 \\
5.1-\mathrm{D} 29\end{array}$ & $60 \times 90$ & 5 & 13.9-D25 \\
\hline 1 & $100 \times 100$ & $\begin{array}{l}1.1-\mathrm{D} 29 \\
6.6-\mathrm{D} 29\end{array}$ & $65 \times 90$ & 5 & 14.4-D25 \\
\hline
\end{tabular}

* 緊張材 : SWPR19（19本より、21.8mm）、鉄笳：SD35

$* * 8,7$ 階の梁鉄筋量は、最小鉄筋比 $(\mathrm{Pt}=0.4 \%)$ で決定
に大きな影響を与えていない。

\subsection{PC 梁部材の曲け耐力と設計用応力との比較}

本項では、‘はじめに’で述べた (2)の問題「PC 鋼材配置に起因す る部材曲げ耐力の上昇が、梁のヒンジ形成を前提とした PC 建物の設 計を困難にするとされているが、どの様な条件において困難となるの か。」という事について検討する。具体的には、PC 梁部材の曲げ耐 力、および $\mathrm{PC}$ 鋼材の曲げ耐力への寄与分を設計用応力と比較し、ど の様な場合に梁部材耐力が設計用応力を大きく上回り、梁ヒンジの形 成を前提とした設計が困難となるかを考察する。

図 6(a)、(b)は、梁断面終局時に PC 鋼材部材の曲げ耐力に寄与する モーメント分 (Mpc : 計算方法いついては付録 1 参照) を、設計用応 力 (Mreq.gir) で除した值 (Mpc/Mreq.gir) と、梁の曲げ耐力 (Mu.gir) を設計用応力で除した值（以下この值を梁の耐力余裕度と呼ぶ）を最 上層を起点に示している。図 6(a)は各層数の $\mathrm{L}=15 \mathrm{~m}$ のモデルについて、 (b)はスパン長の影響をみるため 8 層モデルの $\mathrm{L}=15 、 20 、 25 \mathrm{~m}$ のモデ ルについての值を示している。

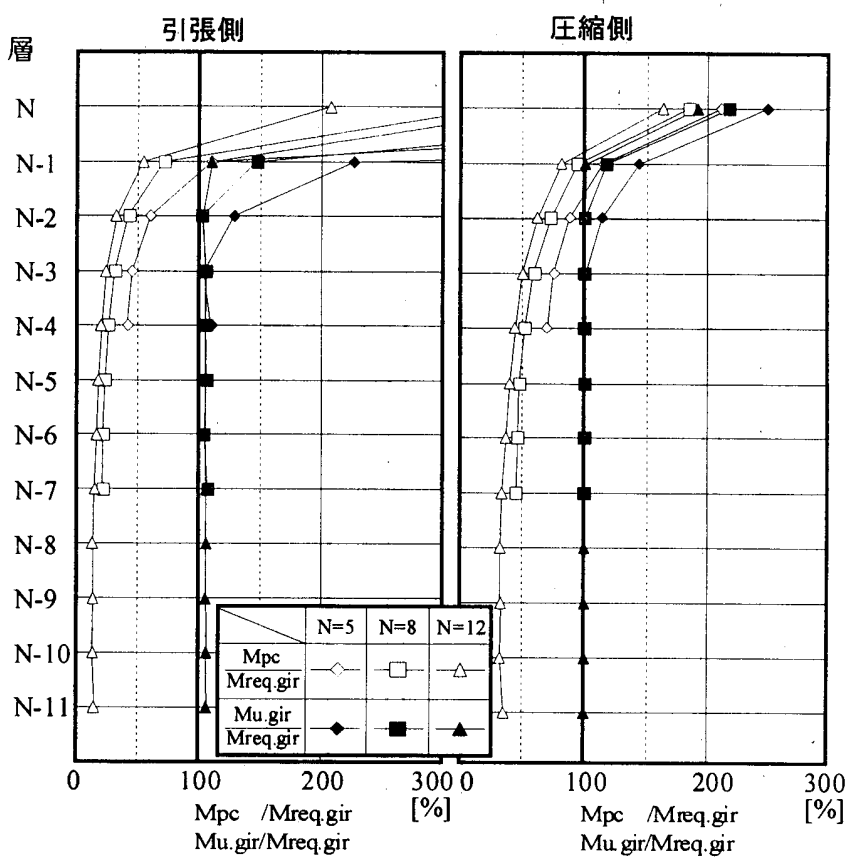

(a) L=15mモデル(建物層数の影籍)

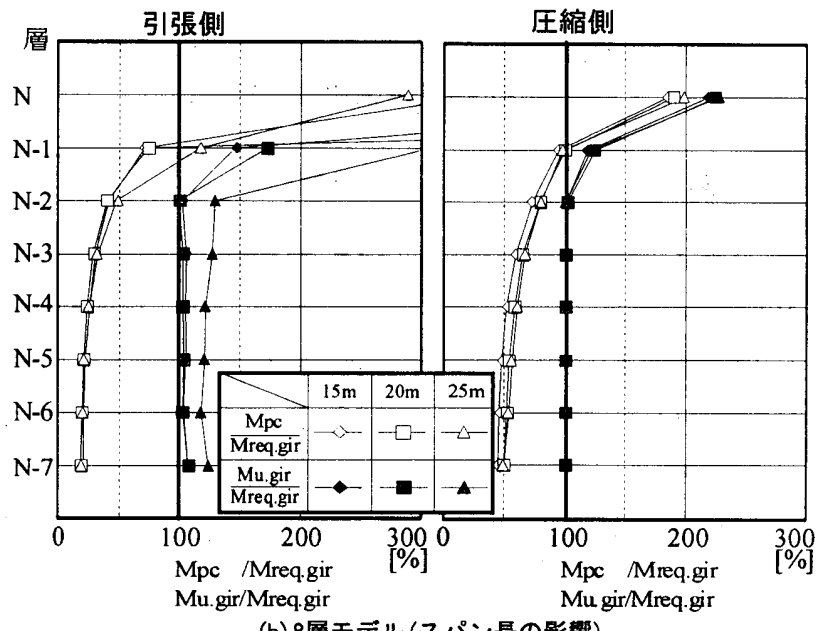

(b) 8層モデル(スパン是の影響)

図-6 PC鋼材が発揮するモーメント及び梁の曲げ耐カの 設計用応力に対する比率 
図 6(a)によれば、Mpc/Mreq.gir の值は、引張側と圧縮側の違い、層 数の違いにより、值の若干の違いはみられるものの、層方向にほぼ同 様の分布傾向を示している。即ち、最上層 ( $\mathrm{N}$ 層) では 1 を大きく越 える值、N-1 層では 1 程度の值、N-2 層以下では下層程その值は淵減 し、各モデル毎にある值に収束する傾向が見られる。次に、梁の耐 力余裕度についてみると、 $\mathrm{N} 、 \mathrm{~N}-1$ 層（PC 鋼材が発生するモ一メン トが設計用応力を上回る層）を除いて、層数、スパン長によらずほぼ $100 \%$ となっており、引張側、圧縮側共に大きな耐力余裕度は発生して いない。

スパン長の影響を調べた図 6(b)によれば、 $\mathrm{L}=15 、 20 、 25 \mathrm{~m}$ の各モ デルのグラフはほぼ重なっており、スパン長が変化しても、 Mpc/Mreq.gir、梁の耐力余裕度の值は殆ど変化しないことがわかる。

ヒンジ発生籄所（梁・柱のいづれにヒンジが発生するか）は、梁だ けではなく柱を含めた検討が必要であるが、最上層および最上層の直 下の層を除けば、PC 鋼材の配置に起因して、梁部材の曲げ耐力が設 計用応力を大きく上回ることはなく、上記 2 層より下の層では梁ヒン ジ形成の可能性があるといえる。

3.3 柱の終局曲げ耐力と設計用応力との比較

本項では、'はじめに’で述べた (3)問題の前半部分「設計用応 力との関連で、柱の部材曲げ酎力の分布がどの様な特徵をもつの か。」について検討を試みる。具体的には、柱部材の曲げ耐力を設計 用応力と比較し、柱の耐力余裕度（曲げ耐力（ Mu.col）を設計用忘 力（ Mreq.col）で除した值）が建物内でどの様な分布となっている かを検討する。

図 7(a)、(b)は、柱の耐力余裕度 ( Mu.col/Mreq.col ) を最上層 (N 層）を起点に引張側、圧縮側別に示したものであり、図 7(a)は各層数 の $\mathrm{L}=15 \mathrm{~m}$ のモデルについて、(b)はスパン長の影響をみるため 8 層モ デルの $\mathrm{L}=15 、 20 、 25 \mathrm{~m}$ のモデルについての值を示している。

図 7(a)によれば、柱の耐力余裕度は、建物高さによらず、引張側で $\mathrm{N}-3$ 層以下、圧縮側で N-2 層以上の層で 100\%となっており、引張側 と圧縮側の耐力余裕度の大小関係は N-2、N-3 層（図中WIIIIIII/,の層）を 境に逆転している。また、同層は他層と比べると引張側、圧縮側共に 耐力余裕度の小さい層（以下 弱層と呼ぶ）であることが分かる。こ れは、2.2 設計用応力の検討 で述べた、 ‘層では引張側、下層では 圧縮側に設計用応力に対する余裕があり、両者の中間に位置するいず れかの層では、引張、圧縮両側共に余裕が小さく、設計用応力に対し、 相対的に弱い層が存在する’ことを具体的に示している。

スパン長の影響を調べた図 7(b)より、スパン長が大きくなるほど弱 層は下層へ移動していることが分かる ( $\mathrm{L}=25 \mathrm{~m}$ のモデルでは N-4、N-5 層 (図中WIIIIII//の層) )。これは、スパン長が大きくなると、鉛直荷重 時応力の影響が他の応力に対し相対的に大きくなることに起因して いる。

\section{4. 静的弾塑性解析による検討}

本節では、 3 節での部材の耐力余裕度から検討した PC 骨組構造の 特徴を試設計モデルの静的弾塑性解析結果と比較し、 $\mathrm{Ai}$ 分布型で規定 される地震荷重条件下でのヒンジ発生籄所および崩壊型について考 察する。

\section{1 解析条件および仮定}

解析モデルの架構形状、断面寸法、およひ配笳量は試設計された值 をそのまま用いて断面剛性及ひ部材耐力を設定した。

$\mathrm{PC}$ 梁及び RC 柱は、部材端部に材端バネを持ち、それ以外の中央部 分は弾性材であると仮定するモデルに置換した。PC 梁の材端バネは、 降伏ヒンジの長さを岡本の提案 ${ }^{8)}$ による塑性ヒンジの等価長さに等し いと仮定し、ひびわれ及び降伏による剛性低下を考慮したトリリニア 一型の曲げモーメントー曲率関係から曲げモーメントー回転角関係 を設定した。この際、ひびわれ、および鉄筋降伏時のモーメントおよ び曲率は平面保持を仮定した断面解析より求めた。又、RC 柱の材端 バネの曲げモーメントー回転角関係は、断面内を 9 分割して鉄筋とコ ンクリートの応力度一丕度の弾塑性関係を直接評価するマルチスプ リングモデルを用いて設定した。同モデルにより、柱の曲げモーメン トー軸力相関関係を考慮することが出来る。

荷重は 2.2 に示す試設計用荷重をすべて考慮した。鉛直荷重及びプ レストレスによる不静定応力は初期荷重として、地震時荷重は、試設 計に用いた設計層せん断力( $\mathrm{Ai}$ 分布)を基準に、比例倍の水平漸増荷重 とした。

\section{2 解析結果}

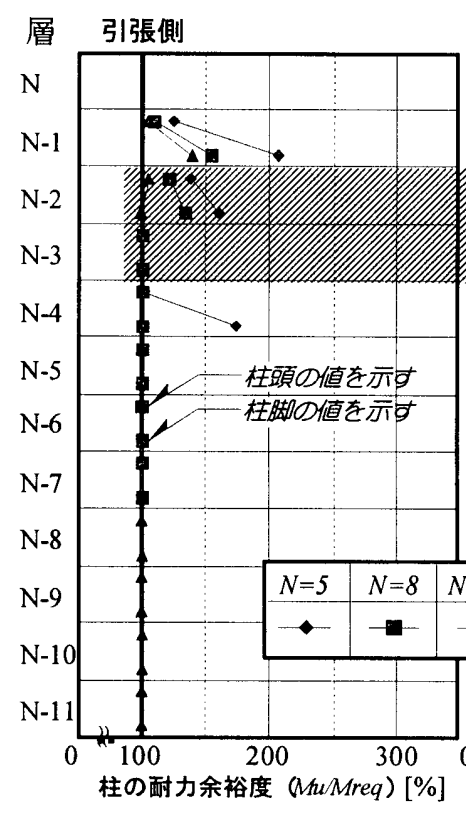

圧縮側

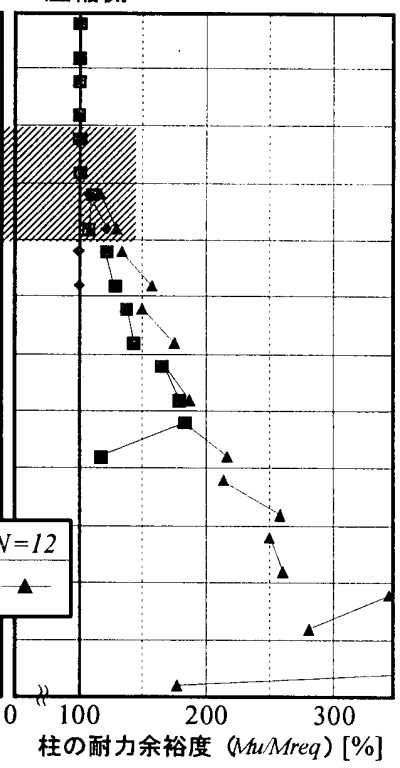

(a) L=15mモデル（建物層数の影響)

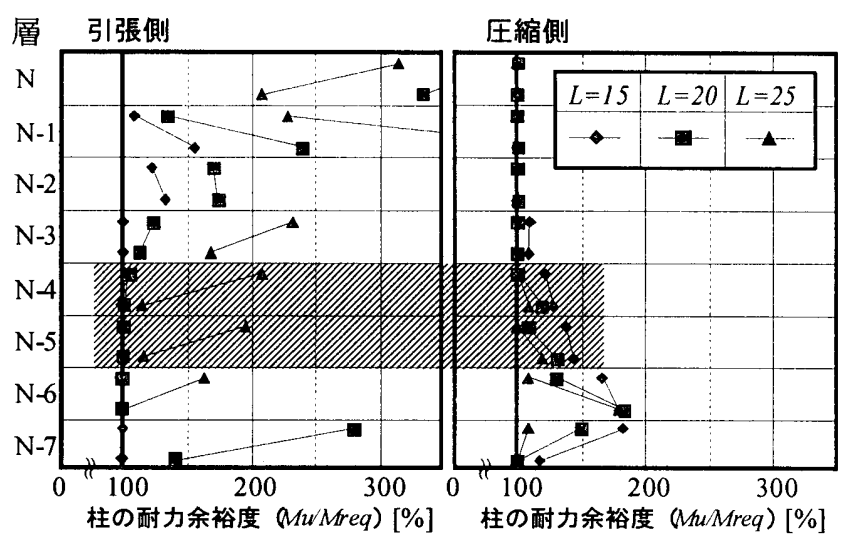

(b) 8 層モデル(スパン長の影檘)

図-7 柱の䩂力余裕度 
静的弾塑性解析より得られた結果を 8 層 $\mathrm{L}=15 \mathrm{~m}$ モデルと、層数が異なるモデルとして 12 層 $\mathrm{L}=15 \mathrm{~m}$ モデル、スパン長が異なるモデ ルとして 8 層 $\mathrm{L}=25 \mathrm{~m}$ モデルについて図 8 に 示す。同図は、層せん断力-層間変形（以下 Q- $\delta$ と略記). 関係および崩壊機構形成時の七 ンジ発生状況図である。

図 8 の Q- $\delta$ 関係によると、崩壊機構形成 時を含むいずれの時点においても、解析にお ける同一ステップで最も変形が大きい層は、 3 節で示した弱層（設計用応力に対し部材の 曲け耐力の余裕が相対的に最も低(層)にほ ぼ一致している。具体的に見ると、8 層 $\mathrm{L}=15 \mathrm{~m}$ モデルでは $\mathrm{N}-3$ 層、 12 層 $\mathrm{L}=15 \mathrm{~m}$ モデ ルでは N-4 層、8 層 $\mathrm{L}=25 \mathrm{~m}$ モデルでは $\mathrm{N}-5$ 層である。

また、同図のヒンジ発生状況図より、いず れのモデルでもヒンジの発生箇所は部材断 面の曲げ耐力余裕度の小さい箇所であるこ とがわかる。例えば 8 層 $\mathrm{L}=15 \mathrm{~m}$ モデルの場 合、図 7(a)より、柱では N-2 N-3 層を境に して上層では圧縮側、下層では引張側の柱の 耐力余裕度が $100 \%$ （即ち曲げ耐力が設計上 要求される耐力とほぼ一致している状態）と なっており、これらの柱頭、柱脚でヒンジが 発生している。また、梁部材については、上 層では引張側、下層では圧縮側にヒンジが発 生している。柱・梁共に耐力余裕度の大きい 最上層 ( $\mathrm{N}$ 層) では、柱・梁共にヒンジは発 生していない。

また、いずれのモデルにおいても、崩壊機 構は、最も耐力余裕の低い層を最下層として 形成しており、引張側の柱の耐力余裕度が大 きくなる同層以下の層を含む形で崩壊機構 を形成する可能性恔小さいといえる。

\section{5. まとめ}

PC 骨組建物の耐震性に関する基本的な構 造特性を把握するために、1 スパンの PC フ レームモデルを現行設計法(建設省告示 1320 号 設計ルート-a 型)に準拠して試設計し、 設計用応力（鈆直荷重時応力、不静定応力、地震時応力）の大きさに ついての検討、設計用応力と試設計建物の部材曲げ而扵力と比較、お よひ静的弾塑性解析を行い、以下の知見を得た。

1) 設計用応力を構成する地震時応力、鉛直荷重時応力、不静定応力の それぞれの割合の傾向を示した。スパン長 $15 \mathrm{~m}$ のモデルでは地震時応 力が設計用応力に対して支配的であるが、スパン長が大きくなると鉛 直荷重時応力が相対的に大きくなり、スパン長 $25 \mathrm{~m}$ のモデルで 5 層以 下の建物では地震時応力と同等以上の值となる。不静定応力の大きさ は、建物の層数によらず各層でほぼ同程度の值であり、鉛直荷重時応
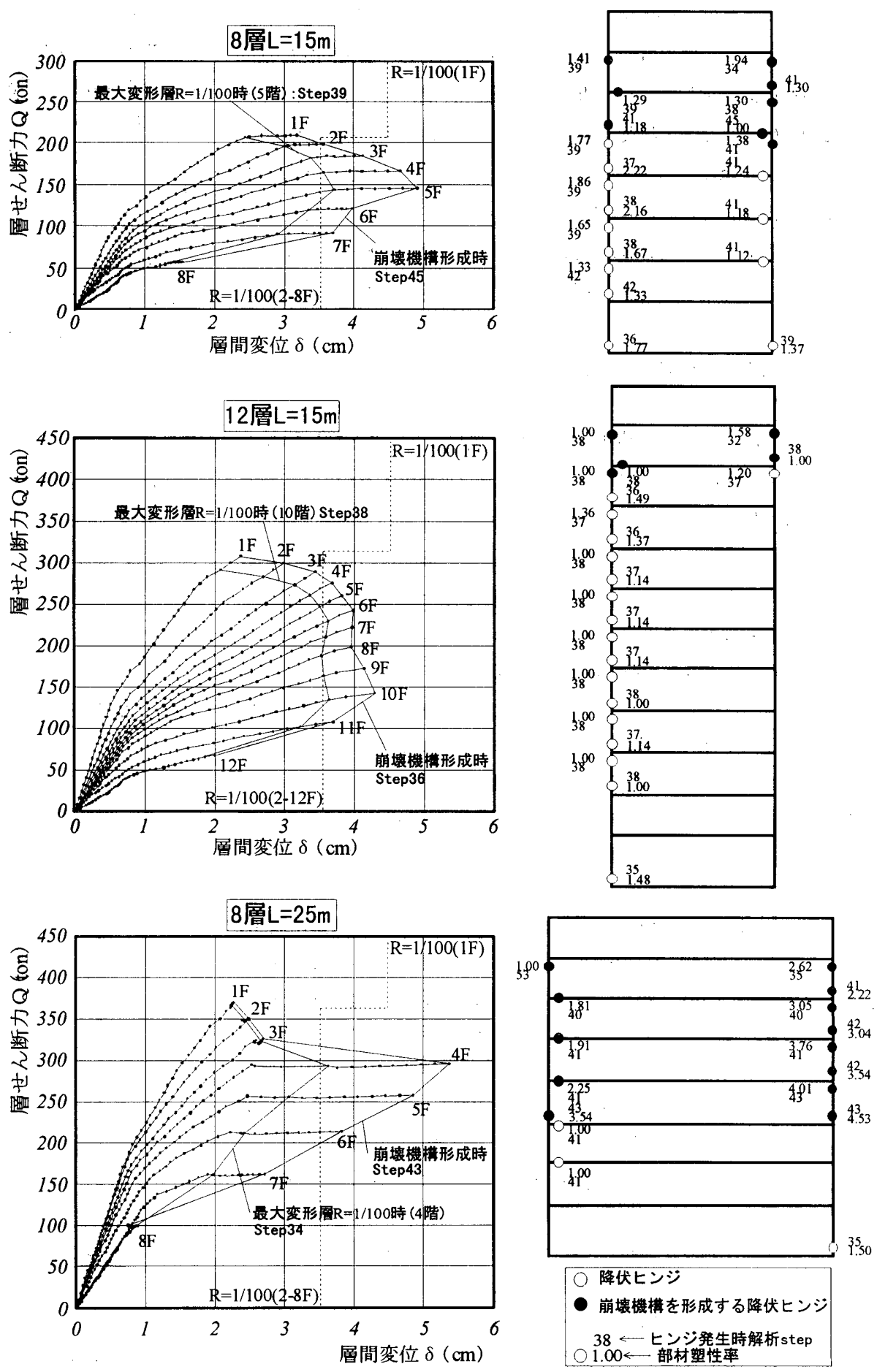

○降伏ヒンジ

○崩壊機構を形成する降伏ヒンジ

38 世早溌生時解析step $1.00 \longleftarrow$ 部材塑性率

図-8＼cjkstart層せん断カ-層間変位関係及びヒンジ発生状況図

力に対しスパン長 $15 \mathrm{~m}$ モデルの柱頭で約 60 ～80\%、柱脚で約 $35 \sim 65 \%$ であった。スパン長 $25 \mathrm{~m}$ のモデルでは柱頭、柱脚共に $15 \mathrm{~m}$ モデルの 值の約半分であった。

2) スパン長、層数によらず PC 鋼材の配置により梁部材の曲げ耐力が 設計用応力を上回る箇所は、最上層およびその直下の層のみであり、 これらの層を除けば梁ヒンジ形成の可能性があることを示した。 3) 柱の曲け耐力に着目して層のせん断耐力をみた場合、設計層せん断 力に対する余裕度が最も小さくなる層 (弱層) が存在することを明ら かにした。弱層は、スパン長が大きい建物程低層に現れる。 
4) 静的弾塑性解析により、上記の弱層は、同一解析ステップで最も変 形の大きな層となること、柱頭、柱脚共にヒンジが形成される可能性 の高いこと、それに起因して同層を含む形で崩壊機構を形成すること を示した。

<参考文献 $>$

1) 日本建築学会:鉄筋コンクリート造建物の勒性保証型而震設計 指針（案）・同解説、1997 年 7 月

2) 深野慶、中塚佶、岸本一蔵、鈴木計夫 :「低層 P C構造の設計用 ベースシアー係数の検討」日本建築学会構造系論文報告集、

No.490、pp.197-206、1996 年 12 月

3) 西山峰広、渡辺史夫、六車熙 : 「PC、PPC 及び RC 骨組の地震応 答性状」、コンクリート工学年次論文報告集、Vol.15 No.2、 pp.1125-1130、1993 年

4) 深野慶、岸本一蔵、中塚佶、鈴木計夫:「終局強度型設計法によ る試設計 P Cフレーム構造の耐震性能について」、構造工学論 文集、VOL.40B、PP.335-344、1994 年 3 月
5) 墚野慶、岸本一蔵、中塚佶、鈴木計夫:「PC 骨組構造の一次固 有周期と終局強度型設計用ベースシア一倸数について」、構造 工学論文集、VOL.41B、PP.477-484、1995 年 3 月

6) 日本建築学会 : 「プレストレストコンクリート設計施工規準 ・ 同解説」、1993 年

7) 日本建築学会 : 鉄筋コンクリート構造計算規準・同解説,1981 年

8) 岡本 伸：「プレストレストコンクリート造骨組架構の耐震性 能に関する基礎的研究」京都大学学位請求論文、1986 年

<付録 $1>$

$$
\begin{aligned}
M p c= & T_{p y} \cdot\left(d_{p c}-x n\right) \\
& \text { ただし、 } x n=\frac{T p y+T r y-C r y}{0.8 \cdot b \cdot F c}
\end{aligned}
$$

ここで、Tpy : PC 鋼材降伏時応力、 $\mathrm{d}_{\mathrm{pc}}$ : PC 鋼材位置、xn : 中立軸位 置、Try : 引張鉄筋降伏時応力、Cry : 圧縮鉄笳降伏時応力、 $\mathrm{b}$ : 梁幅、 Fc : プレーンコンクリートの圧縮強度 